\title{
MULTA PENAL CUMULATIVA: ANÁLISE DE CONSTITUCIONALIDADE EM SUA FIXAÇÃO A CONDENADOS HIPOSSUFICIENTES ${ }^{1}$
}

\author{
Juniara Cristina Fernandes Orthmann²
}

Resumo: Este artigo objetiva avaliar, sob o aspecto constitucional, a multa penal cumulativa fixada aos condenados hipossuficientes. Através de um sistema dedutivo, busca-se demonstrar a colisão de mencionada sanção com princípios constitucionais gerais e penais nos casos de réus desprovidos de pecúnia. Uma vez contextualizado o panorama da multa penal sob enfoque, evidencia-se o conflito constitucional existente entre o arbitramento da multa cumulativa e os princípios da proporcionalidade e eficiência nas hipóteses de apenados carentes. Após, aborda-se a constitucionalidade da sanção pecuniária referida através dos preceitos constitucionais da individualização da pena, responsabilidade pessoal, humanidade da pena e dignidade humana. Ao fim, reconhece-se que a multa penal cumulativa aplicada a réus carentes é desproporcional, ineficaz, não individual e indigna, isto é, inconstitucional, porque atinge a família do condenado quando este é carente e, ainda, inviabiliza a humanização da reprimenda e

10 presente artigo, adaptado para este fim, é fruto de Trabalho de Conclusão de Curso orientado pelo Professor Doutor Alexandre Morais da Rosa e submetido à banca examinadora da Universidade Federal de Santa Catarina como requisito parcial à obtenção do grau de bacharel em Direito no ano de 2011.

2 Pós-graduada em nível de especialização em Direito Público em Curso promovido pela Universidade Regional de Blumenau - FURB em parceria com a Escola Superior da Magistratura do Estado de Santa Catarina (ESMESC). Bacharel em Direito pela Universidade Federal de Santa Catarina (UFSC). Assessora Judiciária lotada na $1^{\text {a }}$ Vara Criminal da Comarca da Capital no período de julho/2009 a abril/2011. Atualmente, Assessora Jurídica junto ao Gabinete da Juíza Titular da Vara da Infância e Juventude da Comarca da Capital, Dra. Brigitte Remor de Souza May. E-mail: juniara_o@hotmail.com 
a dignidade do condenado, que não tem condições de saldar o débito, acarretando-lhe privações que afetam seus direitos sociais.

Palavras-chave: Multa penal cumulativa. Proporcionalidade. Eficiência. Individualização da pena. Hipossuficiente.

\section{INTRODUÇÃO}

$\mathrm{Na}$ busca de meios que solucionem a criminalidade, diferentes reprimendas surgem a fim de ressocializar condenados e de resgatar a paz social, entre tais métodos: a pena de multa.

Em tal diapasão, ante as curiosidades e distintas espécies de multa penal, suscitar-se-á ao longo deste artigo se a multa penal obrigatória, prevista no tipo penal cumulativamente com pena restritiva de liberdade, encontra amparo na Constituição Federal - CF.

Balizando ainda mais o tema, através de um processo dedutivo, analisar-se-á a (in)constitucionalidade da referida sanção pecuniária na aplicação aos condenados hipossuficientes.

Certo é que a pena de multa, justamente por se tratar de sanção pecuniária, implica na diminuição patrimonial do condenado, no entanto, há de se questionar se tal consequência colide com o que se deve esperar da resposta estatal e também das finalidades da pena em casos de hipossuficientes.

Para tanto, contextualizar-se-á ligeiramente o leitor acerca da multa penal e o atual método brasileiro de contagem de referida sanção, o chamado sistema dias-multa.

Após, averiguando a (des)proporcionalidade da multa penal fixada aos réus hipossuficientes, buscar-se-á apreciar a adequação, a necessidade e a proporcionalidade em sentido estrito da referida sanção pecuniária. Logo, questionar-se-á se a pena de multa é apropriada ao fim que se destina e se apresenta a menor restrição (desvantagem) possível de direitos fundamentais, bem como serão destacados seus eventuais benefícios ou inconvenientes e prejuízos, pairando a todo o momento a questão pobreza versus riqueza. 
Ainda, em referida etapa, analisar-se-á - nos termos do artigo 37 da Carta Magna - a eficiência ou não da multa penal fixada em condenação a réus hipossuficientes, abordando-se a falta de condições pelo condenado de pagamento da sanção pecuniária e o movimento estatal operado na cobrança da mesma, além de estabelecer-se um paralelo entre os custos da execução da multa penal e do valor desta.

Após, avaliar-se-á a multa penal e o princípio constitucional da individualização da pena. Isto é, pelo preceito insculpido no artigo 5 XLV, da Constituição Federal de 1988 averiguar-se-á se a multa penal fixada aos réus hipossuficientes respeita o princípio da responsabilidade pessoal, se há transcendência de reprimenda aos entes familiares do réu, sejam eles ascendentes, descendentes ou de laços constituídos por afinidade.

Outrossim, será necessário expor se o princípio da individualização da pena, sob a ótica dos preceitos de humanidade da pena e dignidade humana, autoriza a multa penal fixada aos condenados hipossuficientes.

Uma vez analisada a multa penal frente a princípios constitucionais gerais (proporcionalidade e eficiência) e penais (individualização da pena, responsabilidade pessoal, humanização da pena e dignidade humana), especificar-se-á, ao fim, a característica essencial para se reconhecer a inconstitucionalidade da multa penal cumulativa aos condenados: a hipossuficiência. Conceituar-se-á tal qualidade, procurando definir seus limites em meio aos princípios supra referidos a fim de garantir a aplicação do tema na práxis, aparando eventuais omissões.

Assim, a questão que se buscará responder é: a pena de multa prevista cumulativamente, sob uma ótica constitucional, possui legitimidade quando fixada a hipossuficientes?

\section{MULTA PENAL CUMULATIVA}

Após períodos em que predominavam penas corporais, inúmeros povos - cada qual em seu tempo e com diferente 
intensidade - desenvolveram um sistema de sanções pecuniárias.

Documentos antigos, registrados até mesmo antes de Cristo, já prescreviam a aplicação de espécies de multa para inúmeros delitos, como, por exemplo, o Código de Hamurabi, que reza em seu art. $8^{\circ}$ : "Se um homem roubou um boi ou uma ovelha ou um asno ou um porco ou uma barca, se é de um deus ou do palácio deverá pagar até trinta vezes mais; se for de outra pessoa, restituirá até dez vezes mais. Se o ladrão não tem com que restituir, será morto”.

Influenciado pelo Código de Hamurabi, o antigo sistema de multa dos hebreus é revelado em passagens bíblicas e aplicado desde delitos contra o patrimônio até crimes sexuais e contra a pessoa, conforme se pode observar em Êxodo XXII.

No sistema penal grego, as penas pecuniárias alcançaram amplo emprego, pois a sanção estava ligada à ideia de reparação do dano e penas restritivas de liberdade eram aplicadas excepcionalmente, tanto que reprimendas em pecúnia substituíam até mesmo delitos inicialmente punidos com morte.

Entre os romanos, a sanção pecuniária era guarnecida de humanitarismo e "os pobres estavam mesmo isentos [...]. E, neste caso, segundo Tiraquellus, ela não podia ser convertida em pena corporal" (PRADO, 1993, p. 30).

De acordo com Sznick (1984, p. 19-24), no sistema romano, a multa chegou a ser uma das mais utilizadas, seja com fins de ressarcimento ou de confisco. Porém, a mesma caiu em desuso na época pós-clássica (Direito Justiniano), persistindo sua aplicação para casos como aborto, rixa, pederastia e adultério.

Após o uso de sistema severo de penas corporais e capitais, a pena de multa, no final do século XIX, ressurge como substitutiva frente à luta contra as penas privativas de liberdade de curta duração, uma vez que as mesmas "serviam apenas para desmoralizar e degradar o condenado perante a família e a sociedade, fazendo-o perder o emprego e assim operando em sentido negativo ao de sua pretendida ressocialização" (FRAGOSO, 2004, p. 396). 
Atualmente, a multa penal no sistema brasileiro dá-se de forma principal, isolada, cumulada ou alternadamente e como pena substitutiva da privativa de liberdade, conforme fazem referência os artigos $50, \S 1^{\circ}$, e 58 , caput e parágrafo único, ambos do Código Penal - CP.

A multa sob enfoque é a prevista cumulativamente, que pode sê-lo com a reclusão, a detenção e a prisão simples. Ou seja, a multa penal cumulativa estará prevista no preceito secundário da norma incriminadora juntamente com uma das referidas penas privativas de liberdade.

A reprimenda pecuniária em pauta, supostamente, não implicaria, segundo Dotti (2005, p. 476), em caráter infamante, tal como há na prisão. Ocorre que, uma vez não observado o dever da reprimenda pecuniária ser proporcional às condições econômicas do condenado, há grande risco de que a afirmação supra não corresponda à realidade.

Bitencourt (2008, p. 571) resume a pena de multa nos seguintes termos:

enquanto os penalistas modernos ficam discutindo se a pena de multa é 'o pagamento ou a obrigação de pagar' determinada quantia em dinheiro ao Estado, o mestre peninsular Francisco Carrara nos dá uma definição lapidar: 'se chama pena pecuniária a diminuição de nossas riquezas, aplicada por lei como castigo de um delito'.

Pelo teor do artigo 49, caput e $\$ 1^{\circ}$, do Codex Penal, a pena de multa consiste no pagamento ao fundo penitenciário da quantia fixada na sentença e calculada em dias-multa. Será, no mínimo, de 10 (dez) e, no máximo, de 360 (trezentos e sessenta) dias-multa. O valor do dia-multa será fixado pelo juiz, não podendo ser inferior a um trigésimo do maior salário mínimo mensal vigente ao tempo do fato, nem superior a 5 (cinco) vezes esse salário.

Segundo Hassemer (2005, p. 389-390), 
Este sistema promete a consideração precisa da capacidade de rendimento financeiro do condenado, e com isso uma maior igualdade às vítimas e à justiça; pelo menos garante uma maior transparência da decisão de determinação da pena. $\mathrm{O}$ juiz não tem mais que sopesar a pena de multa em um único processo de decisão, em uma exposição global [...].

O assunto foi assim exposto no art. 20 do Anteprojeto de Código Penal sueco:

'Quando alguém for condenado a uma pena de multa, o Tribunal, atendendo à fortuna do condenado, renda, encargos domésticos e demais circunstâncias que influem na possibilidade de tornar efetivo o pagamento, fixará uma certa quantidade que se considerará como constitutiva da exação que o multado pode sofrer, por dia [...]'(PRADO, 1993, p. 71, destaquei).

Prado (1993, p. 78) anota claramente que o conceito do sistema dias-multa deve:

levar o juiz a se perguntar qual é o montante diário que um condenado pode economizar, ou com o qual pode viver, tendo em conta suas necessidades pessoais, seus encargos e outros fatores econômicos, sem que deva, por isso, cair na miséria ou negligenciar seus deveres familiares. Por conseqüência, a soma que o condenado puder economizar em cada dia corresponde ao valor pecuniário de um dia-multa (destaquei).

Atualmente, conforme dispõe o artigo 49, caput e $\$ 1^{\circ}$, do Estatuto Repressor, para crimes que conjeturam pena de multa, calculando-se essa com base no valor de R \$ 678,00 - salário mínimo vigente a partir de $1^{\circ}$ de janeiro de 2013, estabelecido pelo Decreto 7.872, de 26 de dezembro de 2012 -, a reprimenda pecuniária atingirá no mínimo $\mathrm{R} \$ 226,00$, equivalente à 10 (dez) dias-multa no piso de um trigésimo do salário mínimo. 
Por conta disso, hoje, réus hipossuficientes condenados que mereçam reprimenda (pecuniária) mínima (dez dias-multa), independente de encontrar-se um desempregado, outro percebendo menos de um salário mínimo (realidade do cotidiano brasileiro com carteiras de trabalho não assinadas) e terceiro que receba exatamente tal valor, pagam o mesmo montante, o que - se para aquele que recebe $\mathrm{R} \$ 678,00$ já corresponde a $33,33 \%$ de sua renda - imagina-se quanto pesa aos demais.

Nesse contexto, o revogado sistema penal brasileiro de 1940 instituía que a pena de multa não seria executada se o condenado fosse absolutamente insolvente, sendo a cobrança retomada tão logo a situação econômica do mesmo a permitisse.

Por insolvência absoluta, Bento de Faria entendia "a situação de indigência, de extrema pobreza, ou seja, de miséria. E o estado também em que se encontra quem nada possui e o que porventura possa angariar não chega sequer para prover as necessidades indispensáveis à manutenção própria e da família [...]" (apud PRADO, 1993, p. 55).

Em 1954, Basileu Garcia (1954, p. 449) lecionava:

A insolvência absoluta por ser apreciada em conformidade com um critério legal, o do art. $37, \$ 3^{\circ}$, do Código Penal, que reza: 'O desconto não deve incidir sôbre os recursos indispensáveis à manutenção do condenado e de sua família (art. 39)'. A remissão do art. 39 não deixa dúvida de que se procurou, em verdade, conceituar a insolvência absoluta, para os fins penais previstos neste capítulo da multa, pois o art. 39 declara: 'Não se executa a pena de multa se o condenado é absolutamente insolvente; procede-se, porém, à execução logo que a sua situação econômica venha a permiti-lo'. Considera-se, pois, absolutamente insolvente o réu que não possa pagar a multa sem prejuízo dos recursos indispensáveis à sua subsistência e à da sua família.

No entanto, o texto do revogado art. 39 do Código Penal de 1940 não foi repetido pela reforma de 1984, que - em tal 
contexto - re-estabeleceu o sistema dias-multa e disciplinou que, transitada em julgado a sentença condenatória, a multa será considerada dívida de valor, aplicando-lhe as normas da legislação relativa à dívida ativa da Fazenda Pública.

Logo, indispensável aprofundar o tema sob a ótica de princípios constitucionais, sejam eles gerais ou penais, conforme se fará linhas abaixo.

\subsection{Multa penal e princípios constitucionais gerais}

A Constituição da República Federativa do Brasil de 1988 institui princípios tanto de forma explícita, quanto implícita, diferenciação que, porém, não interfere no dever de vinculação da atividade estatal aos preceitos fundamentais, os quais atuam não apenas como critério interpretativo, mas também como legitimadores e limitadores do ordenamento jurídico infraconstitucional.

Em tal diapasão, imprescindível submeter toda questão ao crivo de princípios constitucionais, inclusive o tema em pauta. Para tanto, a análise da multa penal cumulativa fixada aos condenados hipossuficientes será, por ora, norteada pelos princípios constitucionais gerais da proporcionalidade, implicitamente previsto na Carta Magna, e da eficiência, exposto no art. 37, caput, da Constituição Federal.

Em matéria penal, há quem remeta a aplicação do princípio da proporcionalidade ao artigo 59 do Estatuto Repressor, que estabelece critérios para fixação de pena.

Contudo, Franco (2000, p. 67) lembra que a aplicação de referido preceito é mais complexa do que o reducionismo supra:

o princípio da proporcionalidade exige que se faça um juízo de ponderação sobre a relação existente entre o bem que é lesionado ou posto em perigo (gravidade do fato) e o bem de que pode alguém ser privado (gravidade da pena). Toda vez que, nessa relação, houver um desequilíbrio acentuado, estabelece-se, em conseqüência, inevitável despro- 
porção. O princípio da proporcionalidade rechaça, portanto, 'o estabelecimento de cominações legais (proporcionalidade em abstrato) e a imposição de penas (proporcionalidade em concreto) que carecem de relação valorativa com o fato cometido considerado em seu significado global. Tem, em conseqüência, um duplo destinatário: o poder legislativo (que tem de estabelecer penas proporcionais, em abstrato, à gravidade do delito) e o juiz (as penas que os juizes impõem ao autor do delito têm de ser proporcionadas à sua concreta gravidade)'.

A proporção é alcançada, portanto, quando se compatibiliza:

a) adequação teleológica: todo ato estatal passa a ter uma finalidade política ditada não por princípios do próprio administrador, legislador ou juiz, mas sim por valores éticos deduzidos da Constituição Federal - vedação do arbítrio (Übermassverbot); b) necessidade (Erforderlichkeit): o meio não pode exceder os limites indispensáveis e menos lesivos possíveis à conservação do fim legítimo que se pretende; c) proporcionalidade 'stricto sensu': todo representante do Estado está, ao mesmo tempo, obrigado a fazer uso de meios adequados e de abster-se de utilizar meios ou recursos desproporcionais. (BITENCOURT, 2008, p. 25, grifo do autor)

No âmbito da pena de multa, a busca da proporcionalidade estaria, pela redação do Código Penal, no arbitramento do número de dias-multa e do valor dos mesmos nos parâmetros estabelecidos, respectivamente, nos artigos 59 e 60 de referida lei.

Ocorre que, esse método não é suficiente para fixar montantes pecuniários proporcionais no caso de condenados economicamente humildes, que não são auto-suficientes, pois o meio não é apto para atingir o fim (adequação) e, muito menos, o de menor prejuízo possível (necessidade), bem como porque colide frontalmente com a proporcionalidade em sentido estrito. 
A multa penal fixada aos carentes não obedece ao sub-princípio da adequação, pois, para que tal ocorra, "a medida adoptada para a realização do interesse público deve ser apropriada à prossecução do fim ou fins a ele subjacentes" (CANOTILHO, 2003, p. 269), o que não é o caso. Isto porque, com a multa cumulativa não se alcança qualquer objetivo além da imposição de miséria ainda maior ao hipossuficiente e sequer existirá a reparação ao dano, pois a multa penal não é destinada à vítima, e sim ao Fundo Penitenciário, conforme artigo 49 do Código Penal ${ }^{3}$.

Outrossim, muito menos se cumprirá a finalidade precípua da pena e o que se deve esperar da resposta estatal, ou seja, a integração do apenado à sociedade, afinal que adequação pode haver em tornar o pobre mais pobre?

Ao analisar a relação multa e proporcionalidade, Sznick (1984, p. 85) evidencia o que entende ser, talvez a única, falha de tal espécie de pena:

Bentham assinalou que enquanto para uns (os ricos) a multa é uma bagatela, para outros (os que nada tem) é causa de ruína. Sem a proporcionalidade, a pena de multa torna-se injusta ou porque é baixa no máximo (no caso dos que tem posse) ou porque é elevada no mínimo (especialmente para a grande massa de pobres).

Tanto falta adequação na fixação de multa aos carentes que o Projeto Galdino Siqueira, de 1913, não colocou tal reprimenda no quadro das penas por entender, de maneira geral, que a pena pecuniária é "eivada de vício da desigualdade, constituindo uma impunidade para o rico e uma irrisão para o pobre, vício que não desaparece com o alvitre tomado pelo projeto suíço de tornar o calor da multa proporcional às condições econômicas do condenado" (SZNICK, 1984, p. 43).

\footnotetext{
3 Não confundir a multa cumulativa com a pena de prestação pecuniária regulada nos artigos 44 e 45 do Código Penal, pois elas apresentam peculiaridades, distinguindo-se uma da outra. A segunda destina-se à vítima, a seus dependentes ou a entidade pública ou privada com destinação social, tendo caráter primordialmente indenizatório (art. $45, \S 1^{\circ}, \mathrm{CP}$ ); já a segunda reserva-se sempre ao Estado, através do Fundo Penitenciário, possuindo natureza punitiva (art. 49, caput, CP).
} 
A multa penal fixada a hipossuficientes não é proporcional também do ponto de vista do sub-princípio da exigibilidade ou da necessidade, a qual é expressada por Canotilho (2003, p. 270) como "a idéia de que o cidadão tem direito à menor desvantagem possivel. Assim, exigir-se-ia sempre a prova de que, para a obtenção de determinados fins, não era possível adoptar outro meio menos oneroso para o cidadão" (grifo do autor).

O questionamento que se põe neste quadro é: o que é menos limitador aos direitos fundamentais para atingir o fim propugnado de ressocializar o apenado quando se trata da fixação da multa penal, arbitrá-la ou não?

Para responder tal pergunta, é importante observar, a título de exemplo, a redação do artigo 155 , caput e $\$ 5^{\circ}$, do Código Penal. Lido o teor de tais dispositivos, constata-se que a crime mais gravoso ( $\$ 5^{\circ}$ do artigo 155 , Código Penal) comina-se apenas pena restritiva de liberdade, enquanto ao menos gravoso (artigo 155, caput, Código Penal) tem-se, além de pena restritiva de liberdade, a multa.

Alguns doutrinadores disciplinam que tal diferença deu-se por mero esquecimento do legislador. Contudo, a verdade é que, se no furto qualificado (mais gravoso) não há previsão legal de pena de multa, não há sentido algum da mesma existir no furto simples (menos gravoso). É desnecessário castigar mais gravemente conduta menos relevante.

No âmbito da proporcionalidade em sentido estrito, a multa penal arbitrada a pessoas humildes igualmente não encontra legitimidade para sua fixação.

A proporcionalidade em sentido estrito, também chamada de princípio da justa medida, corresponde à inserção de meios e fins, isto é, à avaliação - através de um juízo de ponderação se o meio usado é ou não desproporcionado em relação ao seu fim. Para tanto, há de se sopesar as desvantagens dos meios em relação às vantagens do fim (CANOTILHO, 2003, p. 270).

Parece-me racionalmente prudente deixar de arrecadar receita ao Estado com a fixação de multa (desvantagem) em troca de tornar o hipossuficiente menos carente (vantagem). 
Em verdade, não há como falar em proporcionalidade na fixação de multa aos carentes, pois, em relação ao fim, as desvantagens são inúmeras e vão além de levar o condenado ainda mais à miséria. Como exemplo, Sznick (1984, p. 67), inicialmente, aponta "que a multa pode ser solvida por outrem que não o condenado, assim de multa pessoal pode perder todas as vantagens por ser paga por outrem que não o culpado".

Justamente por tratar-se a multa de montante pecuniário, a questão pobreza versus riqueza sempre permeará referida pena, semeando a desigualdade (desvantagem) de reprimendas dessa espécie quando fixada a condenados economicamente carentes, tornando-se - ao final - desproporcional.

Portanto, muito além de efetuar uma leitura seca do diploma penal, mister analisar que a fixação da pena de multa aos hipossuficientes não está em consonância com a ideia de proporcionalidade. Consequentemente, a fixação de reprimenda pecuniária não é, in casu, a melhor maneira de alcançar o objetivo perseguido pela norma constitucional.

Tal conclusão é, ainda, corroborada pelo princípio da eficiência, o qual busca, em acepção econômica, a racionalização da atividade estatal. Ou seja, através da eficiência, deve-se "obter a maior realização prática possível das finalidades do ordenamento jurídico, com os menores ônus possíveis, tanto para o próprio Estado, especialmente de índole financeira, como para as liberdades dos cidadãos" (ARAGÃO, 2004, p. 75).

Nesse diapasão, a doutrina aponta que a pena de multa possui, em parte, um caráter privativo da liberdade na medida em que impede não necessariamente seu direito de ir e vir, mas afeta a liberdade de consumo, valor ao qual se encontram os cidadãos extremamente apegados nos dias de hoje. Assim, a intervenção do Estado na esfera privada de liberdade do particular só pode acontecer se houver efetivo interesse público nessa intervenção.

No âmbito da pena de multa, inexiste interesse público em impulsionar processos e cobranças infrutíferas desta repri- 
menda quando se tratar de condenados hipossuficientes, pois, justamente por esta última característica, notório que não terão condições financeiras de arcar com o montante, ainda que mínimo, restando a máquina estatal inutilmente movimentada.

$\mathrm{Na}$ prática, o legislador não cuidou "da hipótese mais comum em matéria de pagamento da pena de multa: a do condenado que não possui, em concreto, por ser economicamente hipossuficiente, condições para efetuá-lo. Se é absoluta a carência, não se executa em verdade, a pena de multa" (FRANCO; STOCO, 2007, p. 326), não possuindo, portanto, sua cobrança, e muito menos sua fixação, qualquer eficiência.

Até porque "a experiência demonstra que a grande massa dos condenados por nossa justiça criminal é constituída de marginalizados da sociedade em que vivemos, portadores de atestado público e notório de sua miséria pessoal" (LEAL, 2004, p. 475).

Pierangeli e Zaffaroni (2009, p. 696-697) lecionam acerca da sanção pecuniária em enfoque:

Sua implementação na Europa Central [...] tem alcançado um considerável êxito [...] mas não se pode pensar que venha a ter o mesmo êxito na América Latina, porque as condições sociais são diferentes: a multa não é uma pena adequada para ser imposta aos setores mais carentes de uma população que se encontra no limite de sua subsistência, e que viria agravar, ainda mais, uma situação social que, em definitivo, é uma condicionante ao delito.

Em um sistema onde atualmente se busca dar cada vez mais efetividade às normas, não é compreensível a imposição de pena de multa não passível de cobrança e pagamento.

Frise-se que a não execução do débito inscrito em dívida ativa no caso de apenado carente deve-se não só pelos prejuízos trazidos ao sustento do réu e por força da inviabilidade do pagamento por ele, mas também pelos custos da cobrança - por mais das vezes - ultrapassar o valor a ser executado, não encontrando, assim, qualquer respaldo na concepção de eficiência. 
Tanto é verdadeira referida afirmação que a Lei Catarinense n. 14.266 de 21 de dezembro de 2007, que dispõe sobre o cumprimento do princípio constitucional da economicidade e da suspensão dos processos de execução fiscal de valor inferior a um salário mínimo, em seu artigo $1^{\circ}$ estabelece: "Consideram-se de valor inexpressivo ou de cobrança judicial antieconômica as ações de execução fiscal estadual e municipal, cuja expressão monetária seja inferior a 1 (um) salário mínimo".

Por sua vez, a Circular n. 80/2009 da Corregedoria Geral da Justiça do Estado de Santa Catarina disciplina que "a inscrição em dívida ativa somente ocorrerá quando o mesmo devedor possuir débitos da mesma natureza cujo montante atinja o mínimo de $\mathrm{R} \$ 700,00$, em consonância com o disposto na MP 160/09 do Estado de Santa Catarina", a qual foi convertida na Lei 14.967, de 7 de dezembro de 2009, remetendo-se o leitor ao teor de seu art. $3^{\circ}$.

Uma vez que, nos termos da Circular n. 80/2009 da Corregedoria Geral da Justiça do Estado de Santa Catarina, já se fixou a ideia de que valores inferiores a $\mathrm{R} \$ 700,00$ tem sua cobrança suspensa, não há motivo, ainda que haja ressalva legal, para tal situação não se aplicar aos apenados carentes condenados em multa penal, visto também que "o excesso de execuções fiscais e os valores baixos das multas estabelecidas desestimulam os procuradores e demais agentes da Execução Fiscal a promover a efetiva cobrança" (NUCCI, 2008, p. 382).

Neste sentido, apreciando a apelação crime n. 70006174155 , decidiu a Corte gaúcha:

Quanto à pena cumulativa de multa, transitada em julgado a sentença, passa a ser dívida de valor (art. $51 \mathrm{CP}$ ), exeqüível pela Fazenda Pública, nos moldes da execução fiscal. A cobrança se dá, portanto, por meios extrapenais. A respeito, adoto as conclusões do Encontro de Execução Penal de 2002, no sentido de que cumprida a pena privativa de liberdade e pendente apenas o pagamento da multa cumulativa, deve-se extrair a certidão, remetê-la à 
PGE - órgão competente para executá-la, e extinguir o PEC. Na Consolidação Normativa Judicial da Corregedoria Geral da Justiça (arts. 929 e 933-B) o procedimento é de baixa da pena privativa de liberdade, registrada apenas a execução da multa. Na prática, a cobrança da multa revela-se dispendiosa para o Estado e, de regra, mostra-se inócua, pois o condenado pobre não tem meios para pagála. Não me parece razoável que o Estado fique a gastar tempo e dinheiro para, ao final, chegar ao nada. Na execução da multa como dívida de valor, a realidade social brasileira tem demonstrado que, se algum bem houver passível de penhora, certamente a cobrança atingirá não somente o condenado, mas também seus familiares. Nenhuma pena pode passar da pessoa do condenado, nos termos do art. $5^{\circ}, \mathrm{XLV}, \mathrm{CF}$ e do art. $5^{\circ}, \S^{\circ}$, da Convenção Americana sobre Direitos Humanos, que consagram o princípio da intranscendência. Por tais razões, entendo cabível a isenção do pagamento da multa imposta a condenado que não tem meios para pagá-la, sem prejuízo do sustento próprio e da família. Da mesma forma, quanto às custas processuais, presentes os requisitos para a concessão do benefício da assistência judiciária (arts. 2º 3o e 4o da Lei 1060/50). (Apelação Crime n. 70006174155, Sexta Câmara Criminal do Tribunal de Justiça do Rio Grande do Sul, Relator Marco Antônio Bandeira Scapini, julgada em 21/8/2003).

Por fim, importante suscitar outra questão:

A Fazenda Pública necessita de alguns dados para a execução de multa, sem os quais a atuação estatal é impossivel. Assim, é imperiosa a existência do número do condenado no Cadastro de Pessoa Física (CPF), bem como seu endereço atualizado. Sem tais dados, a Fazenda Pública não admite as informações. [...] A dificuldade trouxe uma situação embaraçosa, visto que a pena aplicada tornou-se inexequivel (MESQUITA JÚNIOR, 2005, p. 310). 
Em âmbito Catarinense, o Código de Normas da Corregedoria Geral da Justiça disciplina, em seu artigo $354, \$ 2^{\circ}$, que emitida a certidão de dívida ativa ou certificada a impossibilidade de fazê-lo por ausência de elementos, registrado o evento relativo à pendência de multa no Sistema de Automação do Judiciário, os autos serão arquivados.

Desta forma, além da falta de riquezas do condenado para pagar a multa a que foi condenado e dos altos dispêndios para cobrança de ínfimos valores, por vezes, a ausência de Cadastro de Pessoa Física e de endereço atualizado sequer permite a inscrição da multa como dívida ativa, conforme prevê o artigo 51 do Código Penal, sendo o processo criminal arquivado e todo um trabalho impulsionado para meros fins de registro a um custo irrazoável, sem qualquer obtenção de benefício.

Consequentemente, se a multa penal, mesmo a de baixo valor, diante de condenados hipossuficientes não se executa, nenhuma legitimidade há em sua fixação, exceto pelo princípio da legalidade, pela leitura isolada do sistema criminal, distanciada especialmente dos demais preceitos constitucionais.

Ocorre que, "o Princípio Constitucional da Eficiência (art. 37, caput, CF) não legitima a aplicação cega de regras legais (ou de outro grau hierárquico), que leve a uma consecução ineficiente ou menos eficiente dos objetivos legais primários" (ARAGÃO, 2004, p. 78).

Portanto, a fixação da pena de multa cumulativa aos hipossuficientes fere, além do princípio da proporcionalidade, também o preceito de eficiência, restando evidenciada a inconstitucionalidade de sua fixação nos casos de apenados com parcos recursos.

\subsection{Multa penal e princípios constitucionais penais}

Conforme se adiantou linhas acima ao colacionar teor de acórdão proferido em apelação crime n. 70006174155 do Tribunal de Justiça do Rio Grande do Sul, julgada em 21/8/2003, a multa penal cumulativa fixada a condenados 
hipossuficientes põe em cheque não apenas os princípios da proporcionalidade e da eficiência, mas também os da individualização da pena, da responsabilidade pessoal, da humanidade da pena e da dignidade da pessoa humana.

A Constituição da República Federativa do Brasil de 1988, em seu art. $5^{\circ}$, inciso XLVI, alínea c, legitima a fixação de multa como pena, destacando claramente a necessidade de se individualizar a reprimenda.

Antes, porém, o inciso XLV de referido artigo evidencia o princípio da responsabilidade pessoal, pelo qual nenhuma pena passará da pessoa do condenado, o que constava da Declaração dos Direitos do Homem já em 1789 e na Declaração de Direitos Humanos de 1948.

Em verdade, os princípios da individualização da pena e da responsabilidade pessoal atrelam-se, na medida em que o primeiro tem por finalidade dar concretude ao segundo, de modo que a responsabilidade penal jamais transcenda o acusado, o qual - se condenado - deve receber sanção em justa medida (NUCCI, 2007, p. 39).

Pelo princípio da individualização da pena quer-se particularizar a reprimenda às circunstâncias concretas do réu. Isto é, almeja-se, na esfera do tema em pauta, evitar que a pena pecuniária seja aplicada sem qualquer análise da situação dos autos e das peculiaridades do acusado, o que, porém, pode ser cada vez mais corriqueiro, diante do escasso ou nenhum fundamento em sentenças quando da aplicação da multa penal cumulativa, atento o julgador, por mais das vezes, apenas à leitura isolada do Estatuto Repressor.

O procedimento que não individualiza a pena e, por conseguinte, não elege "a justa e adequada sanção penal, quanto ao montante, ao perfil e aos efeitos pendentes sobre o sentenciado" (NUCCI, 2007, p. 30) finda por igualar situações econômicas muito distintas, causando profunda incoerência ao sistema.

Nesse contexto, relembre-se da situação anteriormente descrita no tocante aos hipossuficientes condenados à repri- 
menda mínima (dez dias-multa). Independente de encontrar-se um desempregado, outro percebendo menos de um salário mínimo e terceiro que receba exatamente tal valor, todos pagam o mesmo montante, ou seja, igualam-se "os desiguais, sabendo-se, por certo que a prática de idêntica figura típica não é suficiente para nivelar dois seres humanos. Assim, o justo é fixar a pena de maneira individualizada [...]" (NUCCI, 2008, p. 44).

Souza (2006, p. 201) leciona:

Admitir-se que situações diferentes sejam tratadas de maneira igual não é a recomendação do princípio da individualização, muito menos do princípio constitucional da igualdade (art. $5^{\circ}$, caput, $\mathrm{CF} / 88$ ). A reprimenda somente estará corretamente individualizada quando todas as circunstâncias do caso concreto forem, corretamente, ponderadas pelo juiz, pois o princípio da individualização é irrenunciável, sendo imprescindível que as decisões judiciais estendam tais princípios até às máximas possibilidades de instrumentalização prática, posto que, se os juízes estão a eles vinculados, não poderão contrariá-los nas suas decisões.

Juarez Cirino dos Santos (2006, p. 542) afirma:

a pena de multa seria modalidade punitiva definível como pena igual, porque considera desigualmente indivíduos concretamente desiguais; na prática, a seletividade do processo de criminalização, concentrada na população pobre e excluída do mercado de trabalho e do sistema de consumo, frustra a aplicação igualitária da pena de multa.

Assim, a multa penal "trata-se em realidade de um tipo de pena tão criticável quanto a própria prisão, que na prática tem se revelado grandemente inócua, haja vista que a maior parte dos condenados é formada por miseráveis que ordinariamente não dispõem de recursos para pagá-la” (QUEIROZ, 2009, p. 396). 
Nesse diapasão, Boschi (2002, p. 107) discorre:

Num sistema jurídico-penal orientado pela culpabilidade do agente pelo fato mais consentâneo com o objetivo de salvaguarda das diferenças individuais e de resguardo da plenitude da garantia constitucional da individualização da pena o melhor seria a previsão junto aos tipos não de margens de penas mínimas e máximas, como as que possuímos, porque igualmente engessadoras da atividade judicial, mas, isto sim, de penas só com quantidades máximas e não ultrapassáveis.

Não bastassem as críticas oriundas ao tema em pauta pelo princípio da individualização da pena, destaca-se que pelo princípio da responsabilidade pessoal, também conhecido como princípio da pessoalidade ou da intranscendência da pena, busca-se, aplicando o antigo brocardo suum cuique tribuere, dar a cada um o que é seu, ou seja, a sanção penal aplicada pelo Estado deve atingir tão somente o autor da infração penal, jamais seus descendentes, sua família, amigos ou o grupo social em que está inserido. Não é admissível que a pena, privativa de liberdade ou não, seja transferida a terceiros, pois não se pode estirar a pessoas estranhas ao delito, independente de terem elas vínculos com o apenado.

Em que pese a nitidez de tal princípio constitucional, de fato, infelizmente, a transcendência da pena a terceiros ocorre, pois, conforme aduz Devienne Ferraz (apud MARCÃO, 2009, p. 245) ao tratar de desvantagens, a pena de multa, quando atinge condenados carentes, alcança diretamente os familiares, esses privados de parte do ganho de quem lhes provê o sustento.

Boschi (2006, p. 59) evidencia a ofensa à responsabilidade pessoal quando afirma que "É inegável que os efeitos da condenação se projetam reflexamente sobre terceiros inocentes, muitas vezes irreversivelmente. É o que acontece, por exemplo, quando os pais efetuam o pagamento das multas impostas aos filhos". 
Outrossim, Prado (1993, p. 94) destaca que a multa:

[...] 2. Afeta aos familiares do condenado e pode ser paga por terceiros. 3. Pode incitar à prática de novos crimes, para que o condenado adquira condições de pagá-la. 4. Atinge desigualmente as pessoas, já que variam suas possibilidades econômicas, e não é reformadora.

Portanto, frente ao princípio da responsabilidade pessoal, a fixação da pena de multa cumulativa não deveria persistir ao condenado hipossuficiente, até porque, para aquele que pouco e quase nada tem ou recebe, cada centavo possui destino certo, seja de alimentação, moradia, transporte, etc., para si ou a sua prole, companheiro(a), irmãos ou avós, uma vez que - no mais das vezes - persiste o agrupamento familiar.

Inclusive, se - pelo teor do art. 51, caput, do Código Penal e inaplicação no caso sob estudo do art. $4^{\circ}$ da Lei 6.830/80 - é certo que a multa penal não pode passar a pessoa do condenado ${ }^{4}$, impedindo que os herdeiros a paguem quando da morte daquele, não se pode concordar que a pena de multa transpasse à família do apenado hipossuficiente quando esse estiver vivo.

Ferrajoli (2006, p. 382) sustenta que:

A pena pecuniária é uma pena aberrante sob vários pontos de vista. Sobretudo, porque é uma pena impessoal, que qualquer um pode saldar, de forma que resulta duplamente injusta: em relação ao réu, que não a quita e se subtrai, assim à pena; em relação ao terceiro, parente ou amigo, que paga e fica assim submetido a uma pena por um fato alheio.

Na tentativa de se aplicar o preceito do art. $5^{\circ}, \mathrm{XLV}$, da Constituição Federal, quando da individualização da pena pelo

\footnotetext{
4 "A pena de multa é personalíssima, pelo que não atinge a herança deixada pelo condenado. Com a morte, extingue-se o jus puniendi (art. 107, $\mathrm{n}^{\circ} \mathrm{I}$ ), mesmo se houver sentença condenatória e título penal executório. Sendo a multa uma sanção penal que o Estado aplica no exercício de seu direito de punir, desaparecida a punibilidade com a morte do delinqüente, é claro que o Estado não pode mais exigir o pagamento da pena pecuniária" (MARQUES, 1999, p. 193).
} 
magistrado, o mesmo, via de regra, estabelece a reprimenda adequada fazendo uso, para tanto, dos parâmetros estabelecidos em cada tipo penal (PEÑA DE MORAES, 2010, p. 106).

Contudo, no sistema atual, "a lei que autorizar, em qualquer hipótese, o trasbordamento da pena além da pessoa do delinqüente, será inconstitucional, e, mais do que isso, desumana, porque fere o princípio de direito natural e supra-estatal. O mesmo se diga em relação às sentenças" (MALUF, 1986, p. 429).

A compreensão de reprimenda como desumana depende, portanto, da sua intensidade e consequência, sendo diversos os dispositivos apontados na doutrina para reconhecer o princípio da humanidade da pena, dentre eles: art. $1^{\circ}$, III, e $5^{\circ}$, III, XLVI e XLVII, todos da Constituição Federal.

Pelo teor de mencionados artigos, o princípio referido traduz-se em vedação de tortura e de tratamento desumano ou degradante, bem como torna proscritas penas de morte, de caráter perpétuo, de trabalhos forçados, de banimento e demais sanções cruéis, que possuam consequências brutais. Ou seja, é proibida qualquer pena que desconsidere o homem como pessoa.

Em Pierangeli e Zaffaroni (2009, p. 157) encontra-se:

[...] ninguém deve ser submetido a torturas nem a penas ou tratamentos cruéis, desumanos ou degradantes. A essa conseqüência contribui também o princípio da soberania popular, posto que este pressupõe, necessariamente, que cada homem é um ser dotado de autonomia ética pelo mero fato de ser homem, ou seja, que por esta circunstância é capaz de escolher entre o bem e o mal e de decidir a respeito.

É verdade que "não se pode atrelar a dignidade da pessoa humana a condições econômicas [...]. Contudo, é inegável que sem certos pressupostos econômicos não se pode assegurar a ninguém respeito à sua integridade" (AGRA, 2010, p. 120). 
Assim, a certa medida, a fixação de multa aos hipossuficientes pode ser entendida como pena das mais cruéis, por vezes, por retirar do apenado e de sua família o prato de comida do dia, sendo frequente em alguns casos ouvir-se que o crime se deu para suprir referida privação, podendo esse ciclo transformar-se em uma trama viciosa.

Nesse contexto, sobressalta-se a lição de Gomes (2003, p. 68):

Muito embora se sustente que tal enunciado [humanidade da pena] é mais adequado para proibir abusos na fase executória da pena, do que propriamente para impor limites ao legislador penal (mesmo porque foi aquela a sua função originária), é possível interpretá-la no sentido de proibir que sejam produzidas normas que prevejam penas excessivas em relação ao delito.

Isto é, postula-se da pena uma racionalidade e uma proporcionalidade que anteriormente não se viam. Um dos imperativos da racionalidade é o sistema igualitário, o qual determina que duas pessoas, sob as mesmas condições, devem receber penas semelhantes, de modo que pequenas diferenças entre ambas existirão em face da individualização.

No âmbito da multa penal, o grande prejuízo de tal reprimenda "reside no tratamento desigual a respeito de ricos e pobres; inconveniente que não se pode evitar totalmente ainda que se considerem as circunstâncias econômicas do réu [...]" (Jescheck apud BITENCOURT, 2008, p. 573-574).

Ferrajoli (2006, p. 382) corrobora que "a pena pecuniária é uma pena desigual, ao ser sua formal igualdade bem mais abstrata do que a pena privativa de liberdade. Recai, de maneira diversamente aflitiva segundo o patrimônio e, por conseguinte, é fonte de intoleráveis discriminações no plano substancial".

Isto é, mesmo com a aplicação do sistema dias-multa e a consequente análise da peculiaridade financeira de cada apenado, não é possível rechaçar da multa penal seus inconve- 
nientes, sejam eles de desproporcionalidade, ineficiência, desigualdades e outros.

Em tal diapasão, Franco e Stoco (2007, p. 327) lecionam que, ainda que não seja o apenado absolutamente insolvente, a multa penal não deve ser executada quando tal cobrança acarretar miserabilidade que comprometerá o sustento do condenado e de sua família.

De acordo com Sznick (1984, p. 86), "não deve a pena de multa ser exagerada senão será confisco”. Mas como dizer que a mesma não o é quando se trata de réus hipossuficientes que tem prejudicado o seu sustento e de sua família em prol de uma multa penal? Por certo o é, ainda que o valor seja parcelado, pois sempre acarretará ao apenado e a seus entes privações perversas, seja de educação, saúde, alimentação, moradia ou lazer.

A abstenção de quaisquer dos referidos exemplos entra em choque com o artigo $6^{\circ}$ da Carta Magna que os garante como direito social, considerando "o homem além de sua condição individualista, abrangendo-os como cidadãos que necessitam de prestações estatais para garantir condições mínimas de subsistência” (AGRA, 2010, p. 275).

Talvez pior, aludidas privações vão contra um dos objetivos fundamentais da República Federativa do Brasil: erradicar a pobreza e a marginalização e reduzir as desigualdades sociais e regionais (artigo $3^{\circ}$, III, Constituição Federal). Ainda, colide com a própria dignidade da pessoa, a qual é avaliada pelo "complexo de direitos que são inerentes à espécie humana, sem eles o homem se transformaria em coisa, res. São direitos como a vida, lazer, saúde, educação, trabalho e cultura [...]" (AGRA, 2010, p. 120).

Não se pode, portanto, aceitar a multa cumulativa penal na circunstância de um apenado hipossuficiente que terá as mencionadas consequências.

A introdução da dignidade da pessoa humana como princípio constitucional apresenta, além de uma dimensão fundamentadora e orientadora, uma concepção crítica, ou seja, é 
critério para estabelecer a legitimidade de distintas manifestações legislativas (BULOS, 2009, p. 392).

"Comprovados os extremos fáticos que conduziriam a uma violação de tal princípio no caso concreto, entendemos que a sentença, como ato que 'diz o direito' ('jurisdicional', de juris dicere), não pode dizer o antijurídico, ou seja, não pode violar o princípio da humanidade" (PIERANGELI; ZAFFARONI, 2009, p. 157) e, por conseguinte, não cabe ao magistrado fixar multa penal a apenados hipossuficientes, ainda que cumulativa.

O princípio de humanidade das penas possui vigência absoluta, de modo que não deve ser violado nos casos concretos. A lei penal comum deve estar sempre submetida à Constituição "e, por conseguinte, o intérprete das leis penais deve entendê-la no âmbito constitucional, ou seja, o saber do direito penal deve estar sempre sujeito ao que o saber do direito constitucional informar" (ZAFFARONI et al, 2006, p. 319, grifo do autor).

Uma vez que a fixação da pena de multa cumulativa - ainda que no mínimo legal - acarreta transgressão à intranscendência da pena e, inúmeras vezes, revela ofensa à dignidade humana e à não individualização da reprimenda, bem como é aplicada de forma distante das situações do caso concreto, evidente a inconstitucionalidade de seu arbitramento.

Nesse contexto, o magistrado não pode, "[...] em face de violações ou de ameaças de lesão aos direitos fundamentais constitucionalmente consagrados, permanecer num estado de inércia ou de indiferença ou mesmo admitir que o legislador infraconstitucional se interponha indevidamente entre ele e a Constituição" (FRANCO e STOCO, 2007, p. 61).

Inclusive, assevera Bitencourt (2008, p. 577) que, a fim de verificar a "real situação financeira do apenado, o magistrado poderá determinar diligências para apurar com mais segurança a verdadeira situação do delinqüente e para se evitar a aplicação da pena exorbitante, algumas vezes (para o pobre), e irrisório e desprezivel, outras vezes (para o rico)”. 
A finalidade precípua do reconhecimento da condição de hipossuficientes é re-estabelecer a igualdade, pois, através do reconhecimento da inaplicabilidade da multa penal aos economicamente frágeis, aplicar-se a máxima da justiça distributiva, isto é, tratar-se-á com igualmente os iguais e desigualmente os desiguais na medida em que se desigualam.

$O$ julgador deve ser garantidor das normas constitucionais penais, não podendo quedar-se e manter-se inerte frente ao excesso da multa penal cumulativa em casos de apenados carentes, nem the cabendo simplesmente a aplicação da lei seca, mas a interpretação da mesma frente à completude do sistema e à realidade humana, não ilhando a regra penal, mas a vendo constitucionalmente e no âmbito sócio-econômico, em especial nos casos da pena de multa cumulativa fixada a condenados hipossuficientes.

Por tudo que foi acima desvendado, entenda-se por hipossuficiente aquele que, mesmo detendo pequeno patrimônio, é economicamente muito humilde e vê, com o pagamento da multa penal cumulativa, afetado o sustento próprio e de sua família, impondo consequências não condizentes com a dignidade humana e demais direitos sociais garantidos constitucionalmente, sendo extremamente prejudicado, mesmo com o pagamento do valor mínimo da sanção, atualmente, no montante de $\mathrm{R} \$ 226,00$.

\section{CONCLUSÃO}

Após o predomínio de vinganças privadas e penas corporais, diferentes povos desenvolveram o esqueleto das sanções pecuniárias para concebê-las tal como se tem hoje.

No Brasil, adotou-se à multa penal o chamado sistema dias-multa que, na versão inicial do Código Penal de 1940, previa a possibilidade de não execução de tal sanção a condenados absolutamente insolventes. Contudo, ante a reforma do sistema penal, tal cautela extinguiu-se. 
Nesse contexto, questionou-se ao longo deste artigo se a pena de multa cumulativa possui amparo constitucional quando fixada a hipossuficientes.

Inicialmente, sob a ótica de princípios constitucionais gerais, constatou-se que o arbitramento da multa penal cumulativa à hipossuficientes não é plausível.

O princípio da proporcionalidade - em seus três vértices de adequação, necessidade e proporcionalidade em sentido estrito - revelou a impossibilidade em se arbitrar a multa penal cumulativa aos apenados carentes frente às consequências acarretadas em sua fixação, as quais vão contra mencionado preceito. Isto porque referida sanção não é apropriada ao fim que se destina quando se trata de hipossuficientes (adequação), pois apenas aprofunda ainda mais a característica de pobreza do condenado, não estimulando qualquer reintegração, apenas levando-o à ruína.

As vantagens da não fixação da reprimenda pecuniária cumulativa à hipossuficientes são mais fortes do que as desvantagens (proporcionalidade em sentido estrito), impondo-se ainda, com o não arbitramento de tal sanção, a menor desvantagem possível ao condenado (necessidade), haja vista, inclusive, o exemplo de incoerência do crime de furto qualificado (mais gravoso) não prever tal sanção cumulativamente com a pena privativa de liberdade, e o furto simples (menos gravoso) fazê-lo.

Sob o ângulo do princípio da eficiência, a fixação da multa penal perdeu espaço nos casos de hipossuficientes condenados, uma vez que o apenado não possui condições de pagamento da sanção e, se movido o aparato estatal para cobrança do débito, restaria despendido grande trabalho sem se obter seu fim, a arrecadação financeira ao Estado.

Outrossim, ainda que houvesse pagamento, por se tratar de pessoa carente, a multa deveria ser fixada - em sentença condenatória - no mínimo legal, de modo que os custos da cobrança de multa excederiam o valor da própria sanção, não trazendo ao Estado qualquer benefício, o que, de outro norte, 
autoriza - mais uma vez - o não arbitramento da multa penal cumulativa nas hipóteses de condenado hipossuficiente.

Em um segundo momento desta obra, sob a ótica do princípio constitucional penal da individualização da pena, notou-se que, ao cumprir o artigo $5^{\circ}$, XLVI, da Constituição Federal, necessitará o julgador fixar a multa em patamar condizente com a riqueza do apenado, bem como de modo a impedir que o montante transcenda à pessoa do réu. Não é admissível que a família do condenado responda por referida reprimenda, o que, porém, ocorre no caso de hipossuficientes, razão pela qual se reconheceu o desamparo constitucional no arbitramento da multa penal.

A fixação da multa penal em casos de condenados hipossuficientes também imputaria a eles reprimenda não condizente com o princípio da humanidade da pena, bem como acarretaria condições desprezíveis, em desarmonia ao que prescreve constitucionalmente o preceito da dignidade humana, pelo qual se expôs a necessidade em se reconhecer a inconstitucionalidade de mencionada sanção.

Por fim, preocupando-se em reconhecer a aplicação do tema diariamente na prática e aclarando as hipóteses de inconstitucionalidade da multa penal cumulativa, especificou-se o conceito de hipossuficiência, compreendendo-o aos condenados economicamente humildes que, independente de possuírem pequeno ou nenhum patrimônio, não detêm condições financeiras de quitar o valor mínimo da multa penal pelo sistema dias-multa sem que tenham prejudicado seu próprio sustento e de sua família com consequências ofensivas à dignidade humana e aos demais princípios e direitos garantidos constitucionalmente.

Portanto, diante de exposições práticas e principiológicas, através de um método dedutivo, fica evidente a inconstitucionalidade da multa penal cumulativa fixada a condenados hipossuficientes, uma vez que - em síntese - tal sanção pecuniária, por implicar na diminuição patrimonial do condenado, colide 
com o que se pode esperar da resposta estatal e também das finalidades da pena.

Abstract: This article aims to evaluate, under the constitutional aspect, the fine criminal sentenced to fixed cumulative inapt. Through a deductive system, we seek to demonstrate the collision mentioned penalty on constitutional principles and general criminal defendants in cases devoid of pecuniary. Once contextualized overview of the criminal fine under focus, evident in the constitutional conflict between arbitration and the cumulative fine principles of proportionality and efficiency in the event of poor convicts. After, addresses the constitutionality of the penalty referred through the constitutional precepts of individualization of punishment, personal responsibility, humanity's worth and human dignity. At the end, it is recognized that the cumulative criminal fine imposed on indigent defendants is disproportionate, ineffective, not individual and unworthy, that is unconstitutional, because it affects the family of the condemned when that is lacking, and also prevents the humanization of reprimand and dignity of the offender, who can not afford to pay off the debt, causing you hardship affecting their social rights.

Keywords: Cumulative criminal fine. Proportionality. Efficiency. Individualization of punishment. Poor.

\section{REFERÊNCIAS}

AGRA, Walber de Moura. Curso de Direito Constitucional. 6. ed. Rio de Janeiro: Forense, 2010.

ARAGÃO, Alexandre Santos de. O princípio da eficiência. Revista Brasileira de Direito Público - RBDP, Belo Horizonte, v. 4, p. 75-80, jan.2004.

BITENCOURT, Cezar Roberto. Tratado de Direito Penal: parte geral. 14. ed. São Paulo: Saraiva, 2008. 
BOSCHI, José Antonio Paganella. Das penas e seus critérios de aplicação. 4. ed. Porto Alegre: Livraria do Advogado, 2006.

BULOS, Uadi Lammêgo. Curso de Direito Constitucional. 3. ed. São Paulo: Saraiva, 2009.

CANOTILHO, José Joaquim Gomes. Direito Constitucional. 7. ed. Coimbra: Livraria Almedina, 2003.

DOTTI, René Ariel. Curso de Direito Penal: parte geral. 2. ed. Rio de Janeiro: Forense, 2005.

FERRAJOLI, Luigi. Direito e Razão: Teoria do Garantismo Penal. Tradução de Ana Paula Zomer Sica, Fauzi Hassan Choukr, Juarez Tavares, Luiz Flávio Gomes. 2. ed. São Paulo: Editora Revista dos Tribunais, 2006.

FRAGOSO. Heleno Cláudio. Lições de Direito Penal: parte geral. 16. ed. Rio de Janeiro: Forense, 2004.

FRANCO, Alberto Silva. Crimes Hediondos: anotações sistemáticas à lei 8.072/90. 4. ed. São Paulo: Editora Revista dos Tribunais, 2000. .; STOCO, Rui (coord.). Código Penal e sua interpretação: doutrina e jurisprudência. 8. ed. São Paulo: Editora Revista dos Tribunais, 2007.

GARCIA, Basileu. Instituições de Direito Penal. 4. ed. São Paulo: Max Limonad Editor de Livros de Direito, 1954, vol. 1, tomo II.

GOMES, Mariângela Gama de Magalhães. O principio da proporcionalidade no direito penal. São Paulo: Editora Revista dos Tribunais, 2003.

HASSEMER, Winfried. Introdução aos Fundamentos do Direito Penal. Tradução de Pablo Rodrigo Alflen da Silva. 2. ed. Porto Alegre: Sergio Antonio Fabris Editor, 2005.

LEAL, João José. Direito Penal Geral. 3. ed. Florianópolis: OAB/SC Editora, 2004.

MALUF, Sahid. Direito Constitucional. 18. ed. São Paulo: Sugestões Literárias, 1986.

MARCÃO, Renato. Curso de Execução Penal. 7. ed. São Paulo: Saraiva, 2009.

MESQUITA JÚNIOR, Sidio Rosa de. Execução Criminal: teoria e prática: doutrina, jurisprudência, modelos. 4. ed. São Paulo: Atlas, 2005. 
MORAES, Alexandre de. Constituição do Brasil Interpretada. 7. ed. São Paulo: Atlas, 2007.

NUCCI, Guilherme de Souza. Código Penal Comentado. 9. ed. São Paulo: Editora Revista dos Tribunais, 2008. 2007. . Individualização da Pena. São Paulo: Editora Revista dos Tribunais,

PEÑA DE MORAES, Guilherme. Curso de Direito Constitucional. 3. ed. São Paulo: Editora Atlas, 2010.

PIERANGELI, Jose Henrique; ZAFFARONI, Eugenio Raúl. Manual de Direito Penal Brasileiro - parte geral. 8. ed. São Paulo: Editora Revista dos Tribunais, 2009.

PRADO, Luiz Regis. Multa Penal: Doutrina e Jurisprudência. 2. ed. São Paulo: Editora Revista dos Tribunais, 1993.

QUEIROZ, Paulo. Direito Penal: parte geral. 5. ed. Rio de Janeiro: Editora Lumen Juris, 2009.

SANTOS, Juarez Cirino dos. Direito Penal: parte geral. Curitiba: ICPC, Lumen Juris, 2006.

SOUZA, Paulo S. Xavier de. Individualização da pena no Estado Democrático de Direito. Porto Alegre: Sergio Antonio Fabris Editor, 2006.

SZNICK, Valdir. Da pena de multa. São Paulo: Livraria e Editora Universitária de Direito Ltda., 1984.

ZAFFARONI, Eugenio Raúl. BATISTA, Nilo. ALAGIA, Alejandro. SLOKAR, Alejandro. Direito Penal Brasileiro: primeiro volume - Teoria Geral do Direito Penal. 3. ed. Rio de Janeiro: Revan, 2006. 